\section{The Thermal-Mineral Water of Bačka and the Possibilities of its Exploitation}

Bogdanović, Ž.*

Besermenji, Snežana**

\section{Abstract}

Bačka is a region of Vojvodina which spreads between the Hungarian border on north, The Tisa river on east and the Danube river on west and south. This is a relatively small area, 8,671 square $\mathrm{km}$, but it contains significant amount of thermal and mineral water. Only certain number of collectors, with general mineralization up to $4 \mathrm{~g} / \mathrm{l}$ and temperature around $75^{\circ} \mathrm{C}$, are exploited. For the time being, the thermal water of Bačka are used merely for heating spa and sport facilities. Regarding its quality and amount, this water could be used in many different ways beside this one, for example, in agriculture, industry, tourism, etc.

Key words: Bačka, thermal-mineral water, spa

* ŽivanBogdanović,InstituteofGeography, University of Novi Sad, YU, Novi Sad,Trg Dositeja Obradovića 3

** SnežanaBesermenji,InstituteofGeography,UniversityofNoviSad,YU,NoviSad, Trg Dositeja Obradovića 3

\section{Hydro-geological Factors}

The deep structure of the rocks in Bačka can be examined thanks to the detailed gravimetrical, magnetometrical and seismic analyses, as well as, the numerous boreholes (over 2500 m deep) drilled after the World War II.

The oldest rocks date back to the Paleozoic era. They are mostly made of slate and magma and are found at the depth from $1500 \mathrm{~m}$ to $2000 \mathrm{~m}$. The Mezozoic rocks are found mostly in the south of Backa, at the depth of 1300-1400 m (Marinović et al. 1973), and are made of chalky slate, quartz sandstone and marl.

The Cenozioc era is represented by the Paleogene, Neogene and Quaterna- ry sediments. The deep thermal-mineral water and the artesian water of Bačka lay in the Neogene, Miocene and Pliocene sediments.

During the Neogene period, almost entire Bačka was under the sea. The sediments of the Miocene 1 and Miocene 2 can be even $500 \mathrm{~m}$ thick (in Bačka Topola), while they are much thinner in Senta, Mol, Plavna, Stepanovićevo, Žabalj and Mošorin. They are usually found at the depth of 800-1300 m.

Above the Miocene sediments, there are several thick Pont layers from the Pliocene period. Their thickness varies from 300 m, in Mošorin, to 800 m, in Žabalj (Marinović, Kukin, 1972). In Subotica, this layer is $450 \mathrm{~m}$ thick, in Sombor - over 275 m, in Bečej - over 550 m, at the depth from $811 \mathrm{~m}$ to $1370 \mathrm{~m}$.

Above these sediments there is a layer of paludina deposits. It can be found at the depth of 500-700 m, near Žabalj, while, on some other localities, it is closer to the surface. On top, above all these layers, there is a layer of diluvial and alluvial sediments from the Quaternary period.

For the Neogene, Miocene and Pliocene layers it is characteristic that the layers of waterproof clay marl appear al-

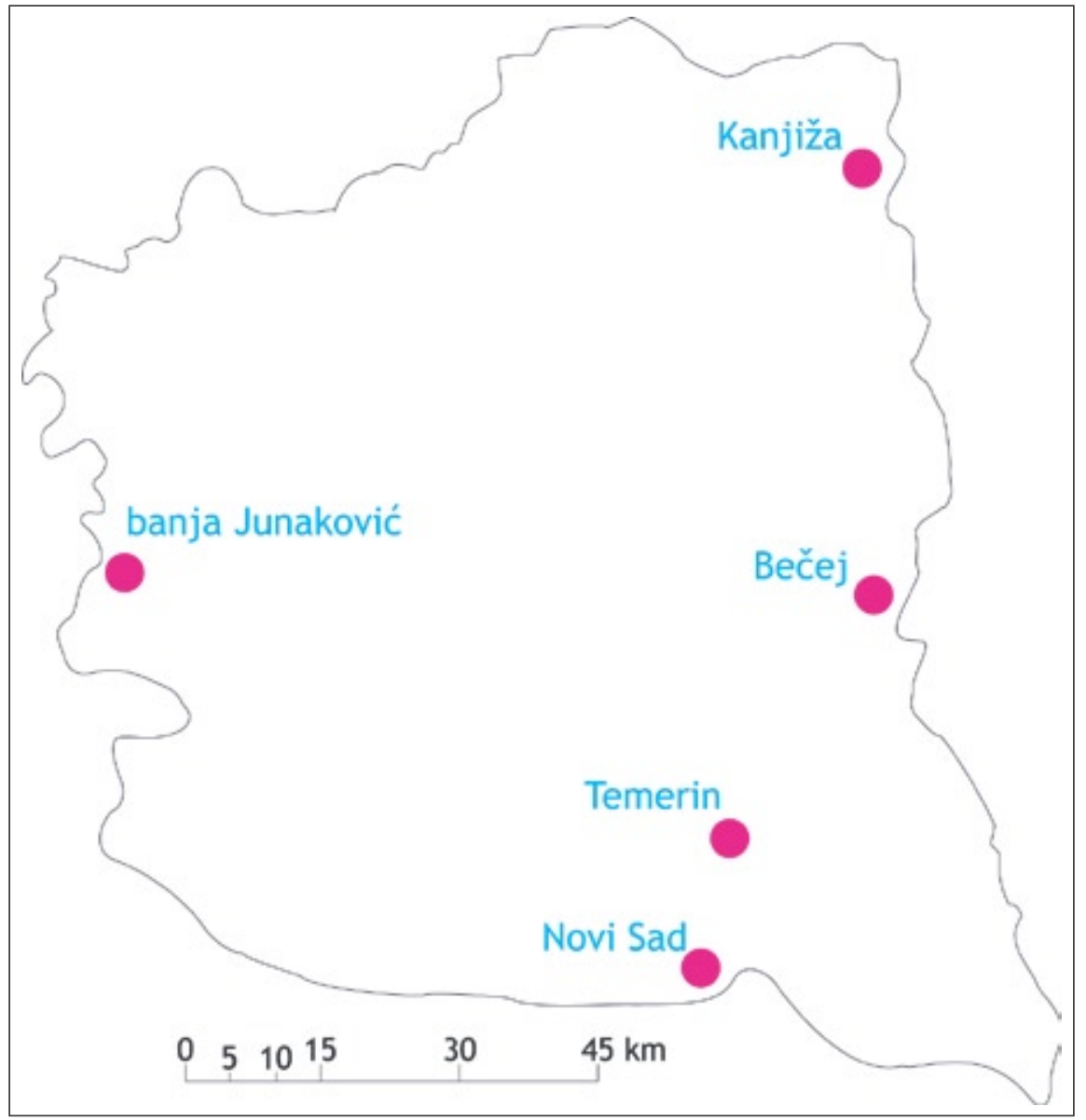

Figure 1. The distribution of thermal-mineral well springs in Bačka 
ternately with the layers of sand or gravel, which collect water. The sediments of Lower Pont era do not have the capability of collecting water. They are represented by thick waterproof layers of clay marl which prevent the water from getting into the pre-Pont layers, thus acting as insulators. Sand and gravel collectors contain artesian water of low mineralization, while the deeper pre-Pont collectors contain konate and juvenile water of high mineralization and temperature.

\section{Chemical Structure and the}

\section{Temperature}

The degree of mineralization of the thermal-mineral water raises with the depth and the age of the collector. The total mineralization usually varies between 3 and $20 \mathrm{~g} / \mathrm{l}$, and the maximum value is over $40 \mathrm{~g} / \mathrm{l}$. According to Aksin and $\mathrm{Mi}-$ losavljevic, there are four different hydro-geological systems in Backa:

1) the first system: the $\mathrm{HCO}_{3}-\mathrm{Na}$ type of the water with the 3-9 $\mathrm{g} / \mathrm{l}$ mineralization;

2) the second system is below the first one and it includes old sediments; the water is of the $\mathrm{HCO}_{3}-\mathrm{Cl}-\mathrm{Na}$ type and the mineralization is $4-20 \mathrm{~g} / \mathrm{l}$;

3) the third system is complex, composed of many different rocks; the water belongs to the $\mathrm{Cl}-\mathrm{Na}$ type and is highly mineralized ( $15-25 \mathrm{~g} / \mathrm{l})$;

4) the fourth system includes igneous, metamorphic and sedimentary rocks; the water has a very low degree of mineralization which makes it suitable for the exploitation.

So far, the first system, with the lowest degree of mineralization, has been examined with the greatest care.

Aksin and Milosavljevic have measured the temperature of the water: on the surface its temperature varies from 25 to $82^{\circ} \mathrm{C}$. The temperature of the water in the collector can be as high as $175^{\circ} \mathrm{C}$. As you go deeper, the water temperature is higher: it increases at $1^{\circ} \mathrm{C}$ per each 18 $m$. Depending on the temperature, the thermal-mineral water belongs to one of the following three groups:

1. thermal-mineral water with temperature between 75 and $90^{\circ} \mathrm{C}$

2. thermal-mineral water with temperature between 50 and $75^{\circ} \mathrm{C}$

3. thermal-mineral water with temperature below $50^{\circ} \mathrm{C}$

\section{The Thermal-mineral Water of Kanjiža}

The town of Kanjiža is located on the north of Bačka, only ten kilometers from the Hungarian border. The first artesian well was made in 1908 and it was 183 m deep. The water temperature was 27.2 ${ }^{\circ} \mathrm{C}$ and the well produced 300-350 I of water per minute. The water contained the following chemical elements: $\mathrm{Na}, \mathrm{K}$, $\mathrm{Ca}, \mathrm{Mg}, \mathrm{Fe}, \mathrm{Al}, \mathrm{Cl}$, as well as oxides, sulfuric acid, $\mathrm{SiO}_{2}$ and carbonic acid. In the year of 1977, the experimental hydrothermal well $\mathrm{Kz}-1 / \mathrm{H}$ was drilled up to the depth of $1147 \mathrm{~m}$, and in 1983, another well $(\mathrm{Kz}-2 / \mathrm{H})$ was made, $1123 \mathrm{~m}$ deep. The captured layers of sand are between 895 and 965 m deep.

The $\mathrm{Kz}-1 / \mathrm{H}$ well produces $2.8 \mathrm{I} / \mathrm{sec}$ and the water temperature is $65^{\circ} \mathrm{C}$. The water belongs to the $\mathrm{HCO}_{3}-\mathrm{Na}$ type. The total mineralization is $3.1925 \mathrm{~g} / \mathrm{l}$ and the salinity is $0.09292 \mathrm{~g} / \mathrm{l}$. The main and prevailing cation in the water is $\mathrm{Na}$ (845.00 $\mathrm{mg} / \mathrm{l})$; the amount of other cations is minor. The dominant anions are hydro-carbonate $(2281.00 \mathrm{mg} / \mathrm{l})$, nitrite (19.50 mg/l) and chloride (17.73 mg/l). The amount of other anions is minor.

The water from the $\mathrm{Kz}-2 / \mathrm{H}$ well is mildly alkaline with $\mathrm{pH}$ 8.3. The well produces $11.8 \mathrm{l} / \mathrm{s}$ and the water temperature is around $65^{\circ} \mathrm{C}$. The total mineralization is $3920 \mathrm{mg} / \mathrm{l}$, and, at the temperature of $180^{\circ} \mathrm{C}$, the amount of sediment is $2630 \mathrm{mg} / \mathrm{l}$. Dominant cation is $\mathrm{Na}(1050.0 \mathrm{mg} / \mathrm{l})$, whereas the presence of others can be disregarded. The main anions are hydro-carbonate (2504.0 $\mathrm{mg} / \mathrm{l})$ and fluorine $(3.8 \mathrm{mg} / \mathrm{l})$. Due to the lack of thermal-mineral water, the third well was made in the year 1996, which produces $12 \mathrm{l} / \mathrm{s}$ and the water temperature is nearly $70^{\circ} \mathrm{C}$.

\section{Exploitation}

The exploitation of thermal-mineral water in Kanjiža started in 1913, when the spa was made. At that time, there was no accommodation within the spa, and the guests had to take rooms in private houses. As the interest for the spa was increasing, the authorities realized that it was necessary to build an accommodation object. This building had 12 rooms, with only 20 beds in total. The turning point in development of the spa was the opening of a new hotel built in 1979. Apart from accommodation, the hotel provides rehabilitation and sport facilities. Rehabilitation facilities include the rooms for Chinese therapy, cabins for paraffin therapy, equipment for electrotherapy and peloide therapy. There are also rooms for inhalation, massage and cosmetic treatments as well as solarium and sauna. All therapies are supervised by doctors. The clinic is an unavoidable part of the rehabilitation center. Sport facilities include two indoor swimming pools. The depth of the bigger one, whose dimensions are $25 \times 12 \mathrm{~m}$, goes from 1.2 to $2.2 \mathrm{~m}$. The smaller pool (dimensions: $10 \times 8 \mathrm{~m}$ ) is for children, and it is only 0.8 $\mathrm{m}$ deep. Both pools contain thermal-mineral water, which is mixed with cold pipe water if needed. As for accommodation, the hotel provides 150 beds distributed in 56 rooms. The restaurant can take 300 guests and it is divided in three parts.

Thermal-mineral water of Kanjza is mainly used for treating rheumatic illnesses, arthritis and hardening or inflammation of spine. Apart from being used for medical purposes, water from the third hydro-thermal well is also used for heating the spa facilities.

\section{The Thermal-mineral Water of the Junaković Spa}

The Junaković spa is located in the northwest part of Vojvodina, $10 \mathrm{~km}$ from the Hungarian border, $2 \mathrm{~km}$ from Apatin, nearby the village of Prigrevica. The first well in this spa was made in 1912. It was $282 \mathrm{~m}$ deep, the water temperature being $22^{\circ} \mathrm{C}$, and the well produced 25 I of water per minute. The experimental hydro-thermal well Prg-1 was $590 \mathrm{~m}$ deep and was made in 1977. This well is giving high quality water which has been characterized as alkaline murijate iodine hypo-thermal water. The water temperature is $25^{\circ} \mathrm{C}$, and the well produces $90 \mathrm{I} / \mathrm{min}$ (Laškov, 1982).

Since 1981 three more hydro-thermal wells have been made: $\mathrm{Pb}-1, \mathrm{~Pb}-2$ and $\mathrm{Pb}-3$. They are all from 700 to $800 \mathrm{~m}$ deep. They go through the layers of Miocene limestone which lay between 600 and $750 \mathrm{~m}$ of depth. Each well produces between 25 and $36 \mathrm{l} / \mathrm{sec}$ and the water temperature is $51-59^{\circ} \mathrm{C}$. The water from the $\mathrm{Pb}-1 / \mathrm{H}$ well is alkaline: $\mathrm{pH}$ being 7.5 . The water salinity is $4.0330 \mathrm{~g} / \mathrm{l}$ and the total mineralization is $5.6306 \mathrm{~g} / \mathrm{l}$. The type of water is $\mathrm{HCO}_{3}-\mathrm{Cl}-\mathrm{Na}$. The dominant cations are: $\mathrm{Na}(1900.00 \mathrm{mg} / \mathrm{l}), \mathrm{K}$ (31.00 mg/l), $\mathrm{NH}_{4}{ }^{+}$ion $(26.80 \mathrm{mg} / \mathrm{l}), \mathrm{Ca}$ (16.30 mg/l) and $\mathrm{Mg}(11.25 \mathrm{mg} / \mathrm{l})$. The main anions are: chloride ( $2447.00 \mathrm{mg} / \mathrm{l})$, hydro-carbonate $(1220.00 \mathrm{mg} / \mathrm{l})$ and sulfate $(4.00 \mathrm{mg} /)$.

The water from the $\mathrm{Pb}-2 / \mathrm{H}$ well is also alkaline, $\mathrm{pH}$ being 7.25 . The total mineralization is $6.4513 \mathrm{~g} / \mathrm{l}$ and the salinity is $4.0915 \mathrm{~g} / \mathrm{dm}^{3}$. The water type is $\mathrm{HCO}_{3}-\mathrm{Cl}-\mathrm{Na}$. The dominant cations are: $\mathrm{Na}(2200.00 \mathrm{mg} / \mathrm{l}), \mathrm{K}(50.00 \mathrm{mg} / \mathrm{l}), \mathrm{NH}_{4}{ }^{+}$ ion $(17.00 \mathrm{mg} / \mathrm{l}), \mathrm{Mg}(15.00 \mathrm{mg} / \mathrm{l}), \mathrm{Ca}$ (9.42 mg/l) and Fe (6.21 mg/l). The main anions are: chloride $(2482.00 \mathrm{mg} / \mathrm{l})$, hydro-carbonate $(1669.00 \mathrm{mg} / \mathrm{l})$ and iodine (9.13 mg/).

The analysis of water from the $\mathrm{Pb}$ $3 / \mathrm{H}$ well shows that the water is alka- 
line, $\mathrm{pH}$ being 7.5. The water salinity is $3.9746 \mathrm{~g} / \mathrm{l}$ and the total mineralization is $5.9360 \mathrm{~g} / \mathrm{l}$. This water is also of the $\mathrm{HCO}_{3}-\mathrm{Cl}-\mathrm{Na}$ type. The dominant cations are: $\mathrm{Na}(2000.00 \mathrm{mg} / \mathrm{l}), \mathrm{K}(25.00$ $\mathrm{mg} / \mathrm{l}), \mathrm{Ca}(17.50 \mathrm{mg} / \mathrm{l}), \mathrm{Mg}$ (12.50 mg/l) and $\mathrm{NH}_{4}{ }^{+}$ion $(14.60 \mathrm{mg} / \mathrm{l})$. The main anions are: chloride $(2411.00 \mathrm{mg} / \mathrm{l})$, hydro-carbonate $(1452.00 \mathrm{mg} / \mathrm{l})$ and iodine (5.00 mg/); (Milosavljevic, 1997).

\section{Exploitation}

The thermal water, produced by the first artesian well made in 1912, was found to be healing. At first, the water was used only for local demand: for treating stomach and rheumatic illnesses as well as illnesses of female genitalia. The first analysis conducted in Budapest showed that, considering the quality, this water can be compared to the famous thermalmineral water of Karlovy Vary and Harkanj. After that, the treatments in this spa took a more professional and organized shape and in the year 1929, the Association of Prigrevica Spa was established. The first ambulance, located near one of the wells, started to work in 1961. It included an indoor swimming pool for hydro-therapy and the accommodation for patients. In time, this ambulance became a part of the Sombor hospital. In 1969, the ambulance employs its first permanent specialized doctor, and the accommodation capacity was enlarged to 84 beds.

The spa became a rehabilitation and recreation center in 1983, when a modern hotel was built and, from than on, the place has been attractive for tourists. The new building has a block of rooms for therapies and an accommodation area. The therapy block covers the area of $1945 \mathrm{~m}^{2}$, and it includes six doctor's offices, an indoor $9 \times 5 \mathrm{~m}$ swimming pool, two saunas, various electro-therapeutic equipment, equipment for Chinese therapy, room for paraffin therapy, inhalation room, laboratory with electrocardiogram equipment and an X-ray machine. One sauna can take 8 to 10 people, and the hydro-therapeutic block can be used by 300 people a day, in two shifts. The accommodation area covers the space of $2722 \mathrm{~m}^{2}$. There are $68 \mathrm{dou}$ ble rooms, four suites and four rooms for the medical staff. There is also a restaurant which can take 220 guests, and a spacious hallway, $577 \mathrm{~m}^{2}$.

The Junaković spa has the important role in the medical tourism in Serbia. The water from this spa has specific chemical and physical features and that is why it is used for treating illnesses like: degenerative rheumatism, illnesses of genitalia, asthma, throat inflammation etc. The conditions for treating the above illnesses are exceptional - the healing water and good accommodation and service. Thus, we have reason to believe that this spa will be very popular in the future as a place for rehabilitation.

\section{The Thermal-mineral water of Temerin}

Temerin is located $20 \mathrm{~km}$ north of Novi Sad, very near the international highway which connects Hungary, via Subotica, Novi Sad, Belgrade and Niš, with Greece and Turkey.

The first borehole in Temerin was drilled in 1914. The well was $417 \mathrm{~m}$ deep and it produced 384 I of water per minute. The water was yellowish, full of sulfur, and its temperature was $29^{\circ} \mathrm{C}$. On account of this thermal-mineral water, two pools and a bath were made on the property of certain Grisa Andrasi. The bath consisted of three rooms with two bathtubs in each and another three rooms with only one bathtub in each. Later, the owner of the building changed, the building was closed for a while and then re-opened in 1982. apart from this bath, which is located in the south part of the town of Temerin, there is a new well, made in 1984, right next to the old road Novi Sad - Temerin - Senta - Horgos, around $100 \mathrm{~m}$ east from the center of the town. The new well produces more water, which is hotter and is used for filling an outdoor swimming pool.

Chemical and mineral analyses were conducted more than once. A complete analysis of both wells was done by "Naftagas", a company for the research and production of oil and gas, in 1984. The following text shows the main results of this analysis.

The outdoor pool with thermal-mineral water is made on the borehole which collects the water from 526 to $707 \mathrm{~m}$ of depth. The water is hot and rich with minerals. The total mineralization is $3.44 \mathrm{~g} / \mathrm{l}$ and the well produces $1340 \mathrm{I} / \mathrm{min}$. The water temperature is $40^{\circ} \mathrm{C}$ and the color is light yellow. The water contains $689.00 \mathrm{mg} / \mathrm{l}$ of hydrocarbonate, $995.00 \mathrm{mg} / \mathrm{l}$ of $\mathrm{Na}$ and 514.17 $\mathrm{mg} / \mathrm{l}$ of chloride.

During the analysis of the well made in 1914, the water was taken from the depth of $417 \mathrm{~m}$. The water is yellowish, and has a characteristic smell. The total mineralization is $2.4 \mathrm{mg} / \mathrm{l}$, the water temperature is $26.5{ }^{\circ} \mathrm{C}$. It contains $680.00 \mathrm{mg} / \mathrm{l}$ of $\mathrm{Na}, 1603.00 \mathrm{mg} / \mathrm{l}$ of hydro-carbonate. The amount of $\mathrm{Mg}$, $\mathrm{Ca}, \mathrm{Fe}$, chloride and iodine is minor. The most dominant of the gases is methane.

\section{Exploitation}

According to Quentin, the thermal-mineral water of Temerin belongs to the hydro-carbonate type, more precisely, to the $\mathrm{HCO}_{3}-\mathrm{Na}$ type. The water is successfully used for treating the following illnesses: degenerative disease, rheumatism, skin diseases, illnesses of genitalia etc. The water has bactericidal effect.

During the research conducted in 2000, the thermal-mineral water of Temerin was used in the bath of the Temerin spa, which is equipped with six rooms with two bathtubs in each. This bath is open during the whole year and functions with the assistance of one doctor and one therapist. The well is located right next to the bath. The water can be drunk directly from the well, but it is not bottled and distributed.

The sport and recreation center includes two outdoor swimming pools. One of them, with dimensions $9 \times 12$ $\mathrm{m}$, is filled with thermal-mineral water. The other one is Olympic pool and is filled with the pipe water. The pools are used only during the summer, which is a big disadvantage considering the quality of the water.

The healing thermal-mineral water of Temerin is well known and in use for the past 86 years. However, Temerin is still a very small medical and recreational center. In the course of these 86 years, only two things were built: a simple bath building with bathtubs and a small outdoor swimming pool (Bogdanović, Vidić, 1989).

\section{The thermal-mineral water of Novi Sad}

The city of Novi Sad is located on the very south of Backa, on the left bank of the Danube river. The first borehole was drilled in 1897, on the location today known as Futoski Park. Later, in the period from 1924 to 1965, another six wells were made. In all six wells the water has the same physical and chemical characteristics, since all of them collect the water from the same water level. To be more precise, the water is collected in the layer of Pliocene sand at the depth varying from $195 \mathrm{~m}$ to 278 $\mathrm{m}$. The wells yield 1.5-4.0 I of water per second. The water temperature is $25^{\circ} \mathrm{C}$, and the water belongs to the $\mathrm{HCO}_{3}-\mathrm{Cl}$ Na type (Laškov, 1982).

On the territory of Novi Sad two more wells were made $n$ the period from 1978 to 1980 . They go through the layers of sand and conglomerates dating from Miocene, which are found at the depth of $420-520 \mathrm{~m}$. The NS-1/H well 
yields $2.0 \mathrm{l} / \mathrm{s}$. The water temperature is $42{ }^{\circ} \mathrm{C}$. The total mineralization is $1.7 \mathrm{mg} / \mathrm{l}$, and the water is alkaline, $\mathrm{pH}$ being 8.5 . The characteristic ions are: $\mathrm{Na}(0.498 \mathrm{~g} / \mathrm{l})$, hydro-carbonate $(0.875$ $\mathrm{g} / \mathrm{l})$ and chloride $(0.266 \mathrm{~g} / \mathrm{l})$. Hydrogensulfate is the only element with healing effect found in this water. The water from the NS-2/H well has the similar characteristics to the previously mentioned water. This well yields $2.8 \mathrm{l} / \mathrm{s}$. The water temperature is at 7 degrees lower, which makes $35^{\circ} \mathrm{C}$ (Milosavljević, 1997).

\section{Exploitation}

The use of thermal-mineral water in Novi Sad started in 1910, when a bath was built. Before the World War I, the bath had six pools and 48 bathtubs. The water had to be additionally warmed and it was enriched by sulfur, carbon acid and pine oil. The water was mainly used for treating rheumatic illnesses, nerve illnesses, vascular diseases, illnesses of female genitalia and inflammation processes in body.

Today, this thermal-mineral water is not used. The baths are filled with pipe water which is than heated. The water from wells NS-1/H and NS-2/H is ignored nowadays, which is a pity, since the presence of hydrogen-sulfate gives this water healing features.

\section{The thermal-mineral water of Bečej}

Bečej is located on the very east of Backa. The water with healing effects was found by accident. In the year of 1904 a borehole was drilled, 380 m deep, and the aim was to find and exploit the combustible gases. However, warm yellowish water sprang out of the well. It was found later that this water contained combustible gas. In 1964, another six wells were made nearby the first one. Their depth varies from 250 to 452 $\mathrm{m}$, and they yield 160-230 I of water per minute. The water is determined as alkaline, slightly acidic hypo-thermal water with a significant amount of iodine and bromine. Its $\mathrm{pH}$ varies from 7.8 to 8.0. Characteristic ions are: $\mathrm{Na}(0.21-0.76 \mathrm{~g} / \mathrm{l})$, hydro-carbonate (1.22-1.99 $\mathrm{g} / \mathrm{l})$ and chlorine (0.029-0.157 $\mathrm{g} / \mathrm{l})$. The water temperature is $31{ }^{\circ} \mathrm{C}$. Before it is used, the water is additionally heated by its own gas (Kukin, 1969).

As a part of the geothermal energy research program conducted in 1984, another well was made, $\mathrm{Bc}-2 / \mathrm{H}$, which is $1020 \mathrm{~m}$ deep. It reaches the layers of sand and sandy soil dating from the Upper Pont era, at the depth of 890-971 $\mathrm{m}$. The well yields $28.1 \mathrm{l} / \mathrm{s}$ and the water temperature at the surface is $63^{\circ} \mathrm{C}$. The water is characterized as $\mathrm{HCO}_{3}-\mathrm{Cl}$, with a significant amount of iodine, bromine, hydrogen-sulfide, meta-boric acid and meta-silicon acid. The total mineralization is $4 \mathrm{~g} / \mathrm{l}$ (Milosavljevic, 1997).

\section{Exploitation}

Thermal-mineral water from the first well was first used in the bath built in 1904. The water contains healing substances and is used for treating bone diseases, skin and eyes diseases, stomach and liver diseases and the illnesses of genitalia. There are six more wells nearby this one, whose water is used for drinking by the local population.

Since the water from the $\mathrm{Bc}-2 / \mathrm{H}$ well is very hot, it is used for heating the buildings of sport center and the "Bela Lađa" hotel. The water is also used for filling an outdoor swimming pool, $50 \times 22 \mathrm{~m}$, and an indoor pool, $33 \times 25$ $\mathrm{m}$, both within the sport and recreation center.

\section{Conclusion}

Bearing in mind the number and capacity of thermal-mineral springs in Backa, as well as the chemical and mineral structure of the water, it can be concluded that the thermal-mineral water of Bačka is not sufficiently exploited, even though there are both demand and opportunities:

The water can be used for medical purposes, in a wider scope and in a better way than the way it has been used by now. The temperature and mineral structure of the water, as well as the good results in treating different diseases completely justify this demand. However, in order to achieve even better results, it is necessary to build modern, well equipped spa centers and employ highly professional staff.

It can be used for sport and recreation activities. A new complex of indoor pools would attract numerous, especially young, population of the whole Backa. This idea is supported by several facts. Firstly, the seaside is too far and expensive for the majority of population, while the rivers and canals are polluted to the considerable extent. Secondly, sport and recreation activities can be performed during the whole year, regardless of the weather, in suitable buildings with thermal-mineral water. Finally, Bačka has a lot of inhabitants and is well connected by roads and highways with other parts of the country.

The water can also be used for heating the buildings. Thermal water represents a cheap and inexhaustible but in- sufficiently exploited source of energy. Considering the present crisis in energy supply in both our country and world in general, geo-thermal source of energy is bound to be used more and more in the future. However, the water from some of the sources would have to be additionally heated, but this would not be a problem considering the initial water temperatures and the fact that water from certain wells contain combustible gases in itself.

Finally, thermal-mineral water can be used in agriculture i.e. in the food production. It would be mainly used for heating hothouses and, thus, producing vegetables even in winter. This idea is supported by the fact that Bačka has a lot of fertile land.

At the very end, it should be emphasized again that the thermal-mineral water of Bačka represent an insufficiently exploited natural resource.

\section{References}

Bogdanović, Ž., Vidić N., (1999): Temerinska termomineralna voda, Zbornik radova, sv. 28, Instituta za geografiju, Novi Sad.

Janković, Z., Belić, S. (1996): Mogućnost korišćenja geotermalnih voda u Vojvodini, Ekologika, Mineralne, termalne i izvorske vode, istraživanje, primena, zatita. Zbornik referata i zaključaka I Naučno-stručnog skupa (Aranđelovac, 1996), Udruženje proizvođača mineralnih voda Jugoslavije, DD, Beograd, strana 269-274.

Kukin, A., (1969): Geološki uslovi pojave arteških voda u Bačkoj i njihove fizizčke i hemijske osobine, Zbornik Matice srpske za prirodne nauke, sv. 37, Novi Sad.

Laškov, M., (1982): Banjski turizam SAP Vojvodine, Prirodno-matematički fakultet, Institut za geografiju, Novi Sad.

Marinović, Đ., Kukin, A., (1972): Kratak prikaz geologije Šajkaške, ŠajkaškaPriroda kraja, Posebna izdanja Matice srpske i Vojvođanskog muzeja, Novi Sad.

Marinović et al. (1973): Osnovni geološki prikaz Vojvodine, Rukopis u Urbanističkom zavodu Vojvodine kao prilog Regionalno-prostornom planu Vojvodine, Novi Sad.

Milosavljević, S., (1997): Lekovite vode Vojvodine. Stručni časopis, Društvo inžinjera inžinjera i tehničara, Novi Sad.

Rekretativno-rehabilitacioni centar "Junaković"

Specijalizovan zavod za medicinsku rehabilitaciju i rekreaciju "Kanjiža" 